\title{
PEMAHAMAN PEMUDA TERHADAP MAKNA KEBAKTIAN MINGGU GEREJA PRESBYTERIAN INJILI INDONESIA JEMAAT SOLA SCRIPTURA MEDAN
}

\author{
${ }^{1}$ Sampitmo Habeahan, ${ }^{2}$ Yakobus Ndona, ${ }^{3}$ Liber Siagian \\ ${ }^{1}$ Prodi Pendidikan Pancasila dan Kewarganegaraan, \\ Fakultas Ilmu Sosial Universitas Negeri Medan, hsampit11@gmail.com \\ ${ }^{2}$ Prodi Pendidikan Pancasila dan Kewarganegaraan, \\ Fakultas Ilmu Sosial Universitas Negeri Medan, yakobusndona@unimed.ac.id \\ ${ }^{3}$ Prodi Pendidikan Pancasila dan Kewarganegaraan, \\ Fakultas Ilmu Sosial Universitas Negeri Medan
}

\begin{abstract}
The objective of this research is to find out how the level of youth understanding about the meaning of Sunday service in Indonesia Evangelical Presbyterian Church (GPII) Sola Scriptura Medan. This research is descriptive it means that the result of the study describe what is in according to the result of the study. Research finding based on the result of observations and interviews concluded that most of the youths have been seriously followed and been active in the Sunday service but there are a few the youths whispered, talked, went in and out of the church when worship taking place. This is in accordance with the result of processed data netted using a closed questionnaire instrument which concluded that $6.3 \%$ of the research subjects were in the very good category, 58,8 $\%$ were in good category and there were $45.15 \%$ were in the bad or bad category. Therefore, the tendency of youth to understand the elements of the meaning of the Sunday service is likely to conclude well. The result of the study indicate the importance of more serious coaching for youth, namely in the form of religious education in schools, fostering parents in the family and supervision of church council when worship taking place.
\end{abstract}

Key words : understanding; youth; the meaning of Sunday service

\begin{abstract}
ABSTRAK
Penelitian bertujuan untuk mengetahui bagaimana tingkat kecenderungan pemahaman pemuda tentang makna kebaktian Minggu di Gereja Presbiterian Injili Indonesia (GPII) Sola Scriptura Medan. Penelitian ini bersifat deskriptif artinya hasil penelitian memaparkan apa adanya sesuai dengan hasil penelitian. Temuan penelitian berdasarkan hasil pengamatan dan wawancara menyimpulkan bahwa sebagian besar di antara pemuda telah serius mengikuti dan aktif dalam pelaksanaan kebaktian minggu. Tetapi tidak sedikit pula di antara pemuda yang berbisik, bercakap dan keluar masuk gereja pada saat kebaktian berlangsung. Hal ini bersesuaian dengan hasil olahan data yang dijaring menggunakan instrument angket jenis tertutup yang menyimpulkan bahwa $6,3 \%$ dari subyek penelitian berada pada kategori sangat baik, 58,8 \% pada kategori baik, masih terdapat sebanyak 45,15\% pada kategori kurang baik dan tidak baik. Sehingga kecenderungan pemuda GPII Sola Scriptura memahami unsur- unsur makna kebaktian pada hari Minggu disimpulkan cenderung baik. Hasil penelitian memberi petunjuk betapa pentingnya pembinaan yang lebih serius kepada pemuda, yakni berupa jalur pendidikan agama di sekolah, pembinaan orang tua dalam kelurga dan pengawasan para penatua gereja sewaktu berlangsungnya kebaktian gereja.
\end{abstract}

Kata kunci: Pemahaman; Pemuda; Makna Kebaktian Minggu 


\section{PENDAHULUAN}

\section{Latar Belakang Masalah}

Pemuda adalah golongan manusia-manusia muda yang masih memerlukan pembinaan dan pengembangan kearah yang lebih baik agar dapat melanjutkan dan mengisi pembangunan yang telah berlangsung. Pemberdayaan pemuda sebagai proses pembelajaran yang dapat dilakukan kapan saja dan dimana saja. Salah satunya dengan melalui kegiatan pembinaan jalur kebaktian gereja.

Pemuda diharapkan agar dengan melalui pembinaan jalur kebaktian minggu dapat menginspirasi generasi milenial gerejani untuk membawa perubahan yang lebih baik, menggalang persatuan antar sesama generasi. Pemuda diharapkan memiliki integritas tinggi, karakter dan kepribadiannya dengan menambahkan nilai-nilai agama, moral, etika dan kejujuran agar generasi penerus bangsa ini berintegritas, pemberani dan berakhlak mulia sehingga mampu meneruskan tugas dan kewajiban dalam menuntaskan ragam persoalan bangsa.

Tetapi walaupun telah banyak harapan dan upaya yang telah dilakukan untuk meningkatkan integritas pemuda, hasil pengamatan di lapangan menunjukkan masih banyaknya pemuda pada umumnya dan pemuda Kristen pada khususnya yang ikut-ikutan tawuran, demo dan kegiatan kenakalan lainnya.

Pada kebaktian di gereja misalnya masih banyak di antara mereka datang ke gereja karena ikut-ikutan, tidak serius beribadah, malah ribut. Berdasarkan pengamatan di GPII Sola Scriptura Medan, jumlah pemuda yang sering mengikuti kebaktian minggu belum menggambarkan jumlah keseluruhan pemuda yang ada. Mereka juga masih suka terlambat, berbisik- bisik dan bermain handphone saat ibadah berlangsung. Menurut peneliti hal itu terjadi karena kemungkinan pemahaman mereka yang kurang baik tentang makna kebaktian minggu. Dari uraian di atas tampak adanya kesenjangan antara harapan dengan kenyataan, sehingga penelitian ini mendesak untuk dilakukan.

\section{Rumusan Masalah}

Bagaimanakah tingkat kecenderungan pemahaman Pemuda terhadap makna kebaktian minggu di GPII Sola Scriptura Medan.

\section{Tujuan Penelitian}

Berdasarkan latar belakang masalah dan rumusan masalah penelitian ini bertujuan untuk mengidentifikasi tingkat kecenderungan pemahaman pemuda terhadap makna kebaktian minggu di GPII Sola Scriptura Medan.

\section{Kontribusi Penelitian.}

Hasil penelitian ini diharapkan dapat memberi kontribusi teoritis dan kontribusi praktis sebagai berikut: kontribusi teoritis dimana hasil penelitian ini memberikan sumbangan yang berarti untuk memperkaya ilmu pengetahuan di bidang teologi dan menambah kajian konseptual yang berhubungan dengan pemahaman pemuda tehadap makna kebaktian di GPII Sola Scriptura Medan. Hasil penelitian akan meningkatkan kontribusi ilmiah melalui publikasi hasil penelitian ilmiah di jurnal ilmiah tentang pemahaman pemuda terhadap makna kebaktian di gereja.

Kontribusi Praktis dimana hasil penelitian yang diperoleh dapat memberikan gambaran tentang pengembangan pemahaman pemuda terhadap makna kebaktian di GPII Sola Scriptura Medan yang berdampak pada peningkatan kualitas pemuda pada umumnya. Hasil penelitian ini dapat dijadikan referensi dan sebagai studi banding untuk penelitian serupa. Hasil penelitian ini dapat dimanfaatkan sebagai bahan bandingan dan rujukan untuk penelitian-penelitian yang relevan dengan jalan melibatkan varibel yang lebih rumit dan kompleks. 


\section{TINJAUAN PUSTAKA}

\section{Pemahaman Pemuda Terhadap Makna Kebaktian Minggu \\ a. Pemahaman Pemuda}

Pemahaman berasal dari kata paham yang artinya pengertian, pengetahuan yang baik, pendapat, pikiran, aliran, pandangan, mengerti benar (akan), tahu benar, pandai dan mengerti benar, apabila dapat imbuhan menjadi memahami yang berarti mengetahui benar. ${ }^{1}$ Menurut Sujadna bahwa pemahaman adalah tipe hasil belajar yang setingkat lebih tinggi. ${ }^{2}$ Sedangkan menurut Kuswana menyatakan pemahaman adalah keterampilan dan kemampuan intelektual yang menjadi tuntunan di sekolah. ${ }^{3}$ Artinya ketika seorang dihadapkan pada suatu komunikasi seperti halnya aktivitas pemuda yang sedang mengikuti kebaktian minggu misalnya, diharapkan ia akan mengetahui apa yang sedang dikomunikasikan dan selanjutnya dapat menggunakan ide- ide yang terkandung di dalamnya.

Pemahaman merupakan penguasaan sesuatu dengan pikiran. Karena itu, belajar yang dalam hal ini kegiatannya dalam megikuti kebaktian minggu berarti harus mengerti secara mental makna dan filosofinya, maksud dan implikasi serta aplikasi-aplikasinya, sehinga menyebabkan seseorang dapat memahami sesuatu. Pemahaman sangat penting bagi pemuda yang medengarkan sesuatu komunikasi dalam kebaktian minggu, karena memahami maksudnya dan menangkap maknanya merupakan tujuan akhir dari belajar melalui kebaktian minggu di gereja. Pemahaman tidak hanya sekedar tahu, tetapi juga menghendaki agar subjek belajar dapat memanfaatkan bahan-bahan yang dipahami.

Masih dalam hubungannya dengan pemahaman dimana adanya beberapa faktor yang mempengaruhi pemahaman, diantaranya: faktor lingkungan, dan faktor instrumental. ${ }^{4}$ Faktor lingkungan yakni berupa lingkungan sosial, lingkungan tempat tinggal dan lingkungan gereja termasuk suasana selama berlangsungnya kebaktian di gereja. Sedangkan lingkungan instrumental mencakup sejuknya alat- alat musik gereja, program pembinaan terhadap pemuda gereja, dan alat- alat instrumen lainnya seperti sarana dan prasarana yang dimiliki yang dapat membuat kesejukan dan kenyamanan kepada para pemuda selama mengikuti kebaktian, sehingga pemahamannya terhadap makna kebaktian di gereja akan bertumbuh dengan baik.

Pemuda adalah warga negara Indonesia yang memasuki periode penting pertumbuhan dan perkembangan yang berusia 16 tahun sampai 30 tahun. ${ }^{5}$ Menurut Suzanne Naafs dan Ben White bahwa generasi muda atau sering disebutkan kelompok muda dalam konteks kehidupan manusia merupakan bagian dari suatu masyarakat dengan manusia dan fungsi yang strategis. ${ }^{6}$ Keberadannya merupakan aset nasional, namun pada sisi lain diakui pula bahwa keberadaan pemuda merupakan beban berat bagi masyarakat karena perlu pemikiran berbagai jenis kebutuhan, seperti pendidikan, kelayakan hidup, dan lapangan pekerjaan.

Menurut H.A.R Tilar bahwa mentalitas pemuda sangat dipengaruhi oleh Pendidikan. ${ }^{7}$ Pemuda jika dilihat dari pendekatan pedagogis dan psikologis, ditandai oleh satu sifat yang begitu identik dengan pemberontak, berani tetapi pendek akal, dinamik tetapi seringkali melanggar norma dan penuh gairah tetapi sering kali berbuat yang aneh-aneh. Pendekatan pemuda dan kepemudaan merupakan suatu yang romantik, demikian menurut Daya Negeri Wijaya. ${ }^{8}$

\footnotetext{
${ }^{1} \mathrm{http}$;//ethesesuin-malang.ac.id

${ }^{2}$ Sudjana, Metoda Statistika, Padang: Tarsito 2005. hal. 24.

${ }^{3}$ Kuswana, Peran Politik Pemuda: Dinamika Pergerakan Pemuda sejak Sumpah Pemuda 1928 sampai kini. Jurnal DEBAT Edisi Pertama, Agustus 2009, 2.

${ }^{4}$ Daya Negeri Wijaya, (Jurnal Kajian Sejarah dan Pendidikan Sejarah, 2013).

${ }^{5}$ Sekretariat Negara, UU No 40 tahun 2019 tentang kepemudaan (Jakarta: Sekneg 2019).

6 Suzanne Naafs dan Ben White, Generasi Antara: Refleksi tentang studi Pemuda Indonesia (Jurnal Studi Pemuda Vol 1 No 2 September 2012, 91.

${ }^{7}$ H.A.R Tilar, (Jurnal Kajian Sejarah No. 1, 2013)

${ }^{8}$ Daya Negeri Wijaya, ( Jurnal Kajian Sejarah dan Pendidikan Sejarah, 2013), 78
} 
Alasan-alasan tersebut pada dasarnya melekat pada diri pemuda yang jika dikembangkan dan dibangkitkan kesadarannya, maka pemuda dapat berperan secara alamiah dalam kepeloporan dan kepemimpinan untuk menggerakkan potensi-potensi dan sumber daya yang ada dalam masyarakat, sehingga pemahamannya tentang makna kebaktian gereja akan senantiasa meningkat.

Wahyu Ishardino Satries mengatakan pemuda adalah salah satu pilar yang memiliki peran besar dalam perjalanan kehidupan berbangsa dan bernegara, sedikit banyaknya ditentukan oleh pemikiran dan kontribusi aktif dari pemuda. ${ }^{9}$ Begitu juga dalam lingkup kehidupan bermasyarakat, pemuda merupakan satu identitas yang potensial dalam tatanan masyarakat sebagai penerus cita-cita perjuangan bangsa dan sumber insani bagi pembangunan bangsa, karena pemuda sebagai harapan bangsa dapat diartikan bahwa siapa yang menguasai pemuda akan menguasai masa depan. Merupakan identitas yang potensial dalam tatanan masyarakat gerejani, sehingga diperlukan pemahaman yang baik terhadap makna kebaktian yang berlangsug di gereja. Jadilah pemuda gerejani dengan pemikiran dan kontribusi aktif dan memiliki pemahaman baik terhadap kebaktian gereja sehingga para pemuda Kristen dapat menjadi insan yang sangat berguna untuk gereja terlebih untuk Nusa dan Bangsa. Hendaknya dipahami bahwa pemahaman yang baik tentang makna mengikuti kebaktian minggu adalah: memahami makna nyanyian sebagai jawaban terhadap firman Tuhan yang disajikan penghotbah, memahami makna votum, memahami makna penyembahan, makna memahami doa ucapan syukur, memahmi makna sepuluh firman sebagai cermin, makna pengakuan dosa, memahami makna pengakuan iman rasuli, memahami makna khotbah, memaknai makna persembahan, memaknai syafaat dan memahami makna doa Bapa kami.

\section{b. Makna Kebaktian Minggu}

Kebaktian minggu adalah kebaktian untuk mensyukuri karya keselamatan umat manusia oleh pengorbanan Yesus Kristus di kayu salib di bukit Golgata, dan perjanjian pribadi kepada Tuhan bahwa masing-masing mau setia kepadanya sampai pada kesudahan hidup di dunia ini. Kehadiran pada kebaktian minggu termasuk bukti ketaatan kepada firman Tuhan. ${ }^{10}$

Malcolm Brouwnle mengatakan kebaktian adalah upacara yang dilakukan jemaat dimana kegiatan itu sebagai bentuk penghambaan kepada Tuhan. Karena memang demikianlah adanya sebab manusia adalah seorang hamba. ${ }^{11}$ W.J.S. Poerwadarminta berpendapat bahwa: ibadah atau kebaktian adalah suatu perbuatan untuk menyatakan bakti pada Tuhan. ${ }^{12}$ Sementara Diater Becker, berpendapat bahwa: kebaktian adalah pertemuan para anggota jemaat Kristen dimana terjadi memuji Allah dan memberitakan Injil dan di sana Roh Kudus hadir secara teratur. ${ }^{13}$ Dengan demikian kebaktian adalah persekutuan orang-orang percaya dimana mereka menghadap Tuhan dengan nyanyian syukur dan mendengar suara Tuhan. Di sinilah terjadi perjumpaan jemaat dengan Tuhan sebagai Juruselamatnya. Dalam kebaktian minggu tata ibadah yang dipergunakan dalam ibadah adalah sesuai dengan Anggaran dasar dan RumahTangga GPII Sola Scriptura Medan.

Hakekat Kebaktian Minggu, bahwa setiap pada hari Minggu orang Kristen harus beribadah di gereja karena hari itu merupakan hari kemenangan bagi orang-orang percaya. Hal itu menunjukkan dan menyatakan tentang kasih Allah yang sudah memberikan berkat surgawi atau keselamatan kepada manusia. Dalam hal ini Yesus Kristus mati di kayu salib, dikuburkan dan pada hari yang ketiga bangkit dari antara kematian. Sebenarnya sabat pada hari Sabtu seperti yang dilakukan oleh gereja Adven. Akan tetapi kemudian sabat itu menjadi hari minggu, karena berhubungan dengan hari

9 Wahyu Ishardino Satries, Peran Serta Pemuda Dalam Pembangunan Masyarakat (Jurnal madaniedisi, 1989)

${ }^{10}$ Alkitab, Lembaga Alkitab Indonesia, 2017. (Keluaran 28:8).

${ }^{11}$ Malcom Brounle, Tugas manusia dalam dunia milik Tuhan (Jkt: Badan Penerbit Kristen Gunung Mulia, 2019), 23

${ }^{12}$ W.J.S Poerwadarminta, Kamus Umum Bahasa Indonesia, Jakarta: Balai Pustaka (2001), 507

${ }^{13}$ Diater Becker, Pedoman Dogmatika (Jkt: BPK Gunung Mulia, 2019), 287 
Minggu Yesus bangkit dari kematian. Jadi wajiblah orang-orang Kristen beribadah pada hari minggu. Hakekat ibadah minggu adalah sebagai acara penyembahan. Ucapan syukur kepada Tuhan dan mendengar suara Tuhan. ${ }^{14}$ Di sinilah orang-orang percaya bertemu dengan JuruselamatNya. ${ }^{15}$ Itulah sebagai dasar dimana orang Kristen memakai hari Minggu sebagai hari merayakan sabat masa kini. Oleh karena itu kehadiran manusia pada kebaktian Minggu termasuklah sebagai bukti ketaatan manusia kepada firman Tuhan yang berkata ingat dan kuduskanlah hari sabat, demikian menurut Diater Becker. ${ }^{16}$ Kesadaran dan kerinduan mengikuti kebaktian Minggu mempunyai makna yang sangat penting bagi pembinaan iman Kristen.

Menurut Abineno: makna mengikuti kebaktian Minggu yang benar adalah memahami dengan sungguh-sungguh kebaktian atau ibadah tersebut. ${ }^{17}$ Dalam tata ibadah terdapat beberapa bagian penting yang harus diperhatikan: makna nyanyian dalam kebaktian merupakan suatu cara untuk memberitakan firman Tuhan pada waktu bernyanyi. Makna votum adalah pada waktu votum berlangsung harus memiliki rasa takut dan tunduk kepada Tuhan. Makna kesepuluh firman adalah melaksanakan sepuluh Firman Tuhan. Makna pengakuan dosa yaitu manusia dituntut harus tunduk di hadapan Tuhan dan mengakui dosa-dosa. Dalam Wahyu 4,11 dikatakan bahwa makna khotbah adalah pengajaran dan nasehat dari Tuhan. Makna Doa Bapa Kami adalah prinsip doa.

Dalam Kamus Besar Bahasa Indonesia disebutkan adanya lima arti kebaktian, yakni: Perbuatan baik, Upacara agama dalam gereja (berdoa, menyayikan lagu puji-pujian), Rasa tunduk dan hikmat kepada Tuhan, Perbuatan kepada Tuhan, dan kesetiaan kepada Tuhan. ${ }^{18}$

Kebaktian dapat disama artikan dengan kewajiban untuk ungkapan syukur yang memiliki unsur-unsur yang tampak tersusun dan tidak mengikat dan yang dipimpin oleh majelis yang terdiri atas penatua dan diaken dimana liturgi dapat dipahami sebagai bagian tak terpisahkan dari ibadah. Dari hasil pengamatan di GPII Sola Scriptura Medan terdapat beberapa unsur dalam kegiatan kebaktian gereja, antara lain: Nyanyian Rohani, Votum, Penyembahan, Doa Ucapan syukur, Hukum Allah, Pengakuan Dosa, Pengakuan iman Rasuli, Khotbah, Persemahan, Doa syafaat dan Doa Bapa Kami. Berikut dijelaskan masing-masing unsur sebagai berikut:

\section{Unsur-Unsur Kebaktian Minggu}

\section{a. Nyanyian}

Nyanyian merupakan pujian bagi Tuhan yang diucapkan oleh warga jemaat di gereja pada hari Minggu. Dalam kebaktian hari Minggu, orang-orang Kristen bersekutu bersama dengan umat lainnya. Panjaitan dan Lumingkewas mengatakan Tuhan layak menerima pujian atau pengangungan dari umat tebusan Allah. Di sinilah Tuhan dihormati dan disanjung karena Tuhan layak dipuji dan disembah sebab Dialah sumber dari segala yang ada, berkuasa atas apapun yang ada di bumi (kelahiran, karier, dan kematian). ${ }^{19}$

Dalam Perjanjian Lama nyanyian disampaikan oleh para penyanyi. Nyanyian atau pujian merupakan kesenangan bagi Tuhan, karena dengan menyanyi orang percaya mengakui kekuasaan Tuhan. Dalam Perjanjian Baru sulit menemukan secara eksplisit yang menyebut nyanyian, karena berfokus pada kisah kelahiran Yesus dan ajaranNya (Injil). Hakekat nyanyian tidak eksplisit akan tetapi tersirat, tapi bukan berarti Perjanjian Baru mengabaikan pujian misalnya dalam kitab Wahyu 15:1-4 ditemukan pujian.

${ }^{14}$ W.J.S Poerwadarminta, Kamus Umum Bahasa Indonesia, Jakarta: Balai Pustaka (2001),

15 Jeremia Djadi. Spritual Seorang Pelayan Tuhan (Jurnal Stt Jaffray Vol 10 No 1,1012 )

${ }^{16}$ Diater Becker, Pedoman Dogmatika (Jkt: BPK Gunung Mulia, 2019), 287

${ }^{17}$ Abineno, J. L. C. Unsur-unsur litugia (10 th ed). BPK Gunung Mulia.2012

${ }^{18}$ W.J.S Poerwadarminta, Kamus Umum Bahasa Indonesia, Jakarta: Balai Pustaka (2001).

19 Rohani Siahaan, Memahami Nyanyian Jemaat Sebagai Sentral Musik Gereja Apa dan Bagaimana?. Jurnal: STT Jaffray. Vol 10, No 2 (2012). 
Makna pujian dalam Perjanjian Baru sebagai penghayatan akan kehebatan Tuhan. Pujian dalam Perjanjian Baru menyatu dengan hati bahkan lahir dari hati. Dengan demikian nyayian yang dipanjatkan merupakan hal yang tidak terpisahkan dari orang-orang Kristen. ${ }^{20}$

\section{b. Votum.}

Makna dari kata votum adalah kebaktian dimulai dalam nama Allah Bapa, Anak-Nya Yesus Kristus dan Roh Kudus sehingga hadirat Allah tritunggal hadir melalui kuasaNya secara nyata. Votum dibacakan oleh pemimpin ibadah sebagai ekspresi kehadiran Tuhan dalam ibadah yang sedang berlangsung, dengan diucapkan Allah hadir di tempat ini. Votum diucapkan oleh Liturgis dalam bentuk pernyataan bahwa Allah hadir dalam ibadah sehingga dinaungi oleh kuasa Tuhan Yesus selama ibadah. Votum yang disampaikan pemimpin liturgi adalah sebagai proklamasi tanda kehadiran sehingga selama ibadah berlangsung tetap di dalam nama Tuhan Yesus. ${ }^{21}$

Allah hadir di tengah jemaat-Nya, yang artinya sebuah pengakuan. Oleh karena itu votum sebagai pengakuan dan keyakinan dimana Allah bersama umatNya ada dalam rumah ibadah. Votum disahkan atas dukungan suara pemimpin liturgi dari mimbar. Votum disampaikan oleh liturgis di tengah jemaat maka Allah memberikan pertolongan karena Dia sumber dari segala berkat.

\section{c. Penyembahan}

Arti penyembahan dalam bahasa Yunani adalah tersungkur di hadapan Allah. Penyembahan merupakan sikap pribadi yang mengagungkan Tuhan dan menyadari bahwa dirinya tidak ada apaapanya serta Tuhanlah yang berkuasa atas hidupnya. Dengan demikian menyembah Tuhan hanya meninggikan Tuhan dan tidak ada doa permohonan disampaikan. Karena Allah adalah Roh adanya maka menyembah Tuhan harus dalam Roh dan kebenaran, yang artinya Roh Kudus yang ada dalam diri seseorang itulah yang menggerakkan orang- orang percaya untuk menyembah Tuhan. Menyembah Tuhan dalam Roh dan kebenaran hanya dapat dilakukan orang yang telah dilahirkan baru. ${ }^{22}$ Rasul Paulus mengajak agar anak-anak Tuhan menjadikan tubuhnya sebagai persembahan yang hidup dan ibadah yang sejati. ${ }^{23}$

\section{d. Doa Ucapan Syukur}

Mengucap syukur bagian dari gaya hidup orang-orang Kristen sebab kebiasaan bersyukur ini merupakan kehendak Allah. Orang Kristen mengucap syukur tidak hanya di saat senang ataupun sedang mendapatkan berkat, akan tetapi Allah menginginkan supaya orang Kristen selalu mengucap syukur dalam segala hal (senang, sedih, kesulitan). ${ }^{24}$

Bersyukur merupakan kepuasan akan keputusan Tuhan dalam hidup seseorang baik dalam situasi menyenangkan ataupun tidak. Tuhan juga mengingatkan agar selalu bersyukur atas semua rancangan Tuhan. Bersyukur berarti percaya kepada Allah sepenuhnya atas apapun yang terjadi di dalam kehidupannya. ${ }^{25}$ Oleh karena itu Gereja sebagai tubuh Kristus seharusnya percaya kepada Allah dan mempercayakan hidupnya kepada Tuhan. Karena dibalik ucapan syukur kepada Tuhan merupakan kedewasaan orang Kristen.

${ }^{20}$ G.Riemer Cermin Injil. Ilmu Liturgi (Jkt: YKBK 2015). 40

${ }^{21}$ Anggaran Dasar, Anggaran Rumah Tangga Sinode Gereja Presbyterian Injili Indonesia, (2016). 18.

22 Jefri Wungow, Fandy Oktovines. Pengaruh pujian dan penyembahan terhadap pertumbuhan jemaat. Jurnal: In Theos. Vol. 1 No. 1 (2021).

${ }^{23}$ Ibid

${ }^{24}$ Yonathan Sumarto. Tinjauan Teologis tentang Ibadah bagi pelaksanaan Misi Allah. Jurnal: Jaffray. Vol 17, No 1 (2019).

${ }^{25}$ Nepho Gerson Laoly. Kajian Biblika, Sitematika dan Misi tentang pentingnya Doa Bagi Gereja. Jurnal: Imanuel. Vol 1, No 1 (2020). 


\section{e. Hukum Allah.}

Dalam Alkitab banyak ditemukan perintah maupun larangan. Hukum Allah diperdengarkan kepada jemaat agar semua perintah dilakukan dan semua larangan dijauhkan. Hukum Allah harus ditaati oleh umat Allah, itulah tandanya seseorang telah menerima keselamatan. ${ }^{26}$

Banyak orang yang salah mengerti terhadap hukum Allah, dimana menganggap hukum Allah sudah tidak berlaku lagi. Memang hukum Tuhan tidak dapat menyelamatkan tetapi selama masih hidup seharusnya menjadikannya sebagai pedoman untuk mengatur kehidupan. Mentaati hukum Tuhan adalah sebagai wujud kasih kepada Allah. Hukum Tuhan dilakukan bukan karena paksaan akan tetapi karena mengasihi Tuhan dan mencintai segala ketetapanNya untuk menyenangkanNya. ${ }^{27}$

\section{f. Pengakuan Dosa}

Firman Tuhan mengatakan semua manusia sudah berdosa dan ada di dalam dosa serta tidak mungkin tidak melakukan dosa. Itulah hakekat dari manusia. ${ }^{28}$ Ada orang beranggapan hanya di dalam gereja saja orang bisa mengakui dosanya itulah sebabnya banyak orang datang ke gereja hanya dengan alasan untuk menyelesaikan dosa saja tentu ini pendapat yang tidak benar. Yang benar adalah dimana sajapun orang-orang Kristen bisa mengaku dosa, karena Yesus mati di kayu salib untuk dosa yang pernah dilakukan, sedang dilakukan dan yang akan dilakukan tanpa melihat tempat. ${ }^{29}$

Dosa tidak boleh disimpan akan tetapi harus diselesaikan melalui pengakuan, penyesalan dan komitmen pertobatan. Tidak jarang pengakuan dosa dilakukan tanpa sungguh-sungguh menyadari dosanya. Pengakuan dosa tidak dapat dipisahkan dari kehidupan gereja sebagai orang suci.

\section{g. Pengakuan Iman Rasuli.}

Pengakuan Iman Rasuli dalam ibadah biasanya diucapkan oleh gereja-gereja penganut teologi Lutheran dan Calvinis. Pengakuan Iman Rasuli adalah inti dari semua ajaran Kristen. Dengan demikian Pengakuan Iman Rasuli sebagai ringkasan dari ajaran iman Kristen harus dinyatakan di hadapan Tuhan secara bersama-sama dengan umat Allah. ${ }^{30}$

Prinsip mendasar teologia dari pengakuan Iman Rasuli adalah sebagai berikut: kepercayaan kepada Allah, Bapa yang mahakuasa khalik langit dan bumi. Kepercayaan kepada Yesus Kristus. Kepercayaan kepada Roh Kudus. Kepercayaan kepada penyaliban Yesus, kematian dan kebangkitanNya. Yesus naik kesorga. Gereja yang esa dan persekutuan. Adanya kebangkitan orangorang percaya dan pemberian hidup yang kekal. ${ }^{31}$

\section{h. Khotbah}

Ibadah tanpa disertai dengan Firman maka ibadah itu tidak sempurna. Sebab dengan firman Tuhan anggota jemaat akan bertindak dalam kehidupannya sesuai dengan kehendak Allah. Dengan demikian ibadah yang baik jika Firman mendapat tekanan utama. Harus diakui bahwa berkhotbah merupakan cara menyampaikan maksud Allah kepada umatNya, harus diyakini bahwa khotbah merupakan hal yang paling penting dalam ibadah Minggu. ${ }^{32}$

Dalam Perjamuan Kudus dan baptisan memang Firman Tuhan dibacakan, namun hal itu pun tidak dapat menggantikan peranan khotbah yang disampaikan oleh hamba Tuhan. Karena firman

26 Dessy Handayani. Implemnetasi Hukum Allah dalam matius 22:34-40 bagi pengembangan komunitas Kristen, Jurnal: Stapin. Vol 11, No 1 (2020).

27 Sampitmo Habeahan. Seni dan Keterampilan berkhotbah Teologi pemberitan Firman Tuhan ( Medan CV Mitra 2020) 35

${ }^{28}$ Alkitab, Lembaga Alkitab Indonesia. Jakarta 1994. 1 Yoh 1:9.

${ }^{29}$ Robertus Joko Sulistyo. Dosa dan Rahmat Sakramen Pengakuan - -Dosa Bagi Remaja. Jurnal: JPAK. Vol 7. No 4 (2012).

${ }^{30}$ Darsono Ambarita, Pertahanan Gereja Abad Permulaan: Kanon, Pengakuan Iman, Jabatan Rasuli dan Relevansinya pada Gereja Masa Kini. Jurnal: STTPK. Vol. 6 No. 1 (2020).

${ }^{31}$ Darsono Ambarita, Pertahanan Gereja Abad Permulaan: Kanon, Pengakuan Iman, Jabatan Rasuli dan Relevansinya pada Gereja Masa Kini. Jurnal: STTPK. Vol. 6 No. 1 (2020).

${ }^{32}$ Ibid, 107 
Tuhan bukan sekedar dibacakan dalam bentuk ayat-ayat akan tetapi harus disampaikan dengan uraian dan urapan Roh Kudus. Jutaan orang di seluruh dunia dengan rela datang ke gereja setiap hari Minggu untuk mendengar seorang hamba Tuhan yang mengkhotbahkan firman Allah dalam ibadah. Kerelaan jemaat datang ke rumah Tuhan harus dihargai dengan memberikan Firman Tuhan secara maksimal dan yang terbaik. ${ }^{33}$

\section{i. Persembahan}

Setiap orang Kristen saat beribadah pastilah memberikan persembahan. Persembahan merupakan bentuk ucapan syukur sebagai wujud dari buah iman, sebab orang Kristen harus bersyukur atas semua apa yang telah diberikan oleh Tuhan kepada gerejaNya, apa yang telah diterima oleh umatNya dari Tuhan harus dikembalikan kepada Tuhan. Hakekat persembahan adalah sebagai ketetapan Tuhan yang dilakukan dalam Perjanjian Lama maupun Perjanjian Baru. Secara tegas firman Allah berkata mengenai kewajiban memberi persembahan melalui bentuk material. Prinsip-prinsip pun dijelaskan oleh Tuhan dalam 2 Korintus 9:6-7. Pertama: menabur sedikit akan menerima sedikit, menabur banyak menuai banyak. Kedua: Memberi dengan rela atau jangan dengan paksa. Ketiga: orang yang memberi akan diberkati. ${ }^{34}$

Oleh sebab itu persembahan bukanlah suatu beban berat yang diberikan oleh jemaat kepada Tuhan akan tetapi orang-orang beriman harus mengembalikan kepada Tuhan sebagai wujud ucapan syukur. Allah yang merupakan sumber dari segala berkat dan usaha dari orang-orang percaya diberkati maka wajiblah jemaat mendukung pekerjaan Tuhan melalui persembahan.

\section{j. Doa Syafaat}

Doa syafaat merupakan permohonan yang dipanjatkan kepada Tuhan dengan suatu keyakinan Tuhan akan mendengarnya. ${ }^{35}$ Jika seseorang berdoa kepada Allah berarti dia membutuhkan campur tangan Tuhan atas pergumulan dalam hidupnya. Banyak hal yang terjadi dalam hidup jemaat berupa tantangan dan persoalan hidup sehingga tidak memiliki gairah dalam hidupnya. Maka saat seperti itulah jemaat membutuhkan sentuhan baru dari Allah. Tuhan tidak ingin orang Kristen jatuh dalam dosa, jauh dari Tuhan dan berhenti melayani. Tuhan ingin agar jemaat bangkit dan berkata Tuhan aku mau meninggalkan semua ketidakpercayaan dan ketidakyakinanku dan aku hanya percaya Kepada$\mathrm{Mu}^{36}$

Doa syafaat salah satu bentuk doa dimana jemaat mendoakan orang lain. Dalam menaikkan doa syafaat dapat dilakukan secara pribadi maupun bersama-sama. Doa syafaat bagi orang Kristen harus menjadi suatu kebiasaan karena Tuhan merindukan jemaatNya untuk membangun komunikasi dengan Tuhan. Jemaat harus memelihara komunikasi yang baik dengan Tuhan dengan cara berdoa. Semestinya doa merupakan nafas rohani bagi orang Kristen, maka dengan berdoalah Tuhan bekerja di dalam kehidupan gerejaNya dan Tuhan akan menyatakan mujizatNya. ${ }^{37}$

\section{k. Doa Bapa Kami.}

Doa Bapa Kami merupakan doa yang diajarkan oleh TuhanYesus kepada murid- murid Nya. ${ }^{38}$ Ini merupakan contoh doa yang pernah diberikan dan diajarkan Yesus kepada murid-muridNya. Di sini terlihat dengan jelas contoh dari topik doa orang Kristen. Adapun aspek-aspek yang ada dalam doa yang diajarkan Tuhan Yesus adalah bagian pertama merupakan kesucian dan kehendak Allah. Sedangkan bagian yang kedua adalah kebutuhan sehari-hari manusia yang harus disampaikan kepada

33 Sampitmo Habeahan. Seni dan Keterampilan berkhotbah Teologi pemberitan Firman Tuhan ( Medan CV Mitra 2020)

${ }^{34}$ Abineno J.1. Ch. Unsur-Unsur Liturgika (Jkt:Badan Penerbit Kristen Gunung Mulia, 2013) 269

${ }^{35}$ Mesakh Jasmin, “Konsep Syafaat dalam Rencana Total Allah,” Jurnal Jaffray Vol 4, No 1 (2006): 34-40.m

${ }^{36}$ Jusuf Haries Kelelufna, “Doa Syafaat Untuk Sodom,” Journal Kerusso 6, no. 1 (2021): 1-18.

37 Sampitmo Habeahan. Seni dan Keterampilan berkhotbah Teologi pemberitan Firman Tuhan ( Medan CV Mitra 2020)

${ }^{38}$ Freddy Gunawan, “Interpretasi Doa Bapa Kami Cyprian,” Jurnal: Amanat Agung, Vol 11, No. 2 (2015): 379-398. 
Tuhan. ${ }^{39}$ Doa yang dipanjatkan seseorang harus meliputi: Ada unsur penyembahan, Tuhan adalah Tuhan yang suci, Tuhan sebagai Bapa kita yang siap memberikan berkat-berkat jasmani dan rohani kepada para pemuda. ${ }^{40}$

Kata dimuliakanlah namaMu menunjukan kepada kerinduan dimana semua orang mengenal Allah, juga memiliki pengertian bahwa sebagai umatNya telah dipakai Allah untuk menjadi alatNya. Kata jadilah kehendakMu memberi pengertian bahwa umat harus menyerahkan diri sepenuhNya kepada Allah secara total.

\section{Penelitian Yang Relevan}

a. Marsi Bombongan Bantesalu (Jurnal Teologi, 219), Refelexi Teologis Tentang Makna Ibadah yang Sejati. Pemahaman yang benar terhadap kebaktian akan memiliki hubungan erat dengan kehidupan Kristen. ${ }^{41}$

b. Eddy Banne, Daud Manno (Jurnal Teologi dan pelayanan Kristiani EPHGRAPHE, 2020), Analisis Dasar Teologis Terhadap Pelaksanaan Ibadah Online Pasca pandemic covid 19. Memahami makna teologi kebaktian minggu mewujudkan ketakwaan kepada Tuhan. ${ }^{42}$

c. Fernando Tambunan (Jurnal Teologi dan pelayanan Kristiani EPHGRAPHE, 2020), Teologia Ibadah dan Kualitas Penyelenggaraan Ibadah. Pemahaman yang baru terhadap unsur kebaktian minggu perlu dalam mewujudkan karakter yang baik menurut Alkitab. ${ }^{43}$

d. Debora Nugrahenny Christimoty (STT Babtis Indonesia Semarang, 2019), Tinjauan teologis Tentang Ibadah bagi Pelaksanaan Misi Allah. Pemahaman yang benar tentang kebaktian minggu akan dapat mendekatkan diri kepada Tuhan. ${ }^{44}$

\section{METODOLOGI PENELITIAN}

\section{Metode Penelitian}

Berdasarkan rumusan masalah dan tujuan penelitian yang diajukan, penelitian ini termasuk penelitian expose facto. Dengan demikian data terkumpul dalam penelitian berupa fakta-fakta dari gejala-gejala variable yang ditetapkan tanpa adanya perlakuan khusus. Karena itu metode yang dilakukan dalam penelitian ini disebut metode survei.

\section{Teknik Sampling}

Peneliti memilih lokasi di GPII Sola Scriptura Medan. Populasi dalam penelitian adalah pemuda GPII Gedung Johor sebanyak 130 orang dengan sampel ditetapkan merujuk pada pendapat Suharsimi Arikunto. ${ }^{45}$ Sehingga besar sampel penelitian diambil lebih besar $75 \%$ plus kemungkinan bias higga besar sampel ditetapkan sebanyak 105 orang.

39 Benyamin, Nefry Christoffel. "Spiritualitas Dalam Doa Bapa Kami." Jurnal Abdiel: Khazanah Pemikiran Teologi, Pendidikan Agama Kristen dan Musik Gereja 2, no. 2 (2018): 32-42.

40 Nefry Christoffel Benyamin,"Spiritualitas Dalam Doa Bapa Kami," Jurnal Abdiel: Khazanah Pemikiran Teologi, Pendidikan Agama Kristen dan Musik Gereja Vol 2, No 2 (2018): 32-42.

${ }^{41}$ Marsi Bombongan Bantesalu, Refleksi Teologis Tentang Makna Ibadah Yang Sejati ( Jurnal Teologi :2019)

42 Eddy Bannel, Daud Manno, Analisis dasar Teologis Terhadap Pelaksanaan Ibadah Online Pasca Pandemi Covid-19 (Jurnal Teologi dan Pelayanan Kristiani EPIGRAPHE:2020)

${ }^{43}$ Fernando Tambunan, Teologi Ibadah dan Kualitas Penyelenggaraan Ibadah (Jurnal Teologi dan Pelayanan Kristiani EPIGRAPHE:2020)

${ }^{44}$ Debora Nugrahenny Christimoty, Tinjauan Teologis Tentang Ibadah Bagi Pelaksanaan Misi Allah (Jurnal Sekolah Tinggi Teologi Babtis Indonesia Semarang: 2019)

${ }^{45}$ Suharmi Arikunto, Prosedur Penelitian ( Jkt: Rineka Cipta, 2018), 107 


\section{Teknik Pengumpulan Data.}

Menurut Suharsimi Arikunto bahwa pengambilan data-data adalah proses penerapan penelitian pada masalah yang sedang diteliti. ${ }^{46}$ Adapun tiga cara yang ditempuh untuk memperoleh data: Pertama, Observasi adalah pengamatan cermat dan teliti. Tujuan dari observasi adalah menyesuaikan teori-teori dari kajian pustaka dengan realita yang ada di lapangan. Kedua, wawancara. Kegiatan ini adalah proses tanya jawab terkait rumusan masalah untuk mendapatkan informasi yang sebenar-benarnya. Adapun orang yang diwawancarai adalah orang-orang yang paling tahu dan terpercaya untuk memberikan informasi seputar masalah yang ada. Ketiga, Angket. Angket sebagai pertanyaan dibagi kepada subjek penelitian dengan berurutan dan isinya sesuai dengan keinginan.

Angket yang digunakan telah diuji cobakan sebanyak 37 butir untuk menguji validitas butir dan reliabilitas angket hingga hanya angket yang lolos uji coba sebanyak 25 butir yang lolos hasil uji coba dan yang digunakan menjarig data penelitian. Alternatif pilihan mengikuti format skala Likert sebagai berikut: sangat setuju/ sangat sering $=5$. Setuju/ Sering $=4$. Ragu-ragu $=3$, Tidak setuju/ jarang $=2$, Sangat tidak setuju/ sangat tidak sering $=1$

\section{Teknik Analisis Data.}

Data yang telah diterima dari responden selanjutnya dianalisa dan kemudian dituangkan menjadi bentuk tulisan. Dalam menentukan hasil penelitian data yang telah ditabulasi dianalisis untuk menguji kebenarannya. Teknik pengolahan data yang digunakan dalam penelitian adalah teknik analisis deskriktif kuantitatif sebagaimana disebutkan berikut ini:

Meanskor dihitung dengan formula: $\mathrm{M}=\mathrm{Xo}: \mathrm{N}$

Sedangkan standart Deviasi dihitung dengan formula:

$$
S D=\frac{1}{N} \sqrt{N \sum X 2-\left(\sum X\right)^{2}}
$$

Median diuji dengan formula: $\mathrm{Me}=\mathrm{Fo} \mathrm{Xi} F \mathrm{Fo}$

Modus diuji dengan formula: $\mathrm{Mo}=\mathrm{b}+\mathrm{p}$ b1 $\mathrm{b} 1+\mathrm{b} 2$

Tingkat kecenderungan variable dibuat dalam table kategori menurut Suharsimi Arikunto dalam Manumpak Silitonga $(2015: 106) .{ }^{47}$

Tabel 1. Distribusi Prekuensi dan Kategori skor Variabel Penelitian.

\begin{tabular}{|l|l|l|l|l|}
\hline Kelas & \multicolumn{1}{|c|}{ Interval Kelas } & & \multicolumn{1}{c|}{ F \% } & \multicolumn{1}{|c|}{ Kategori } \\
\hline 1 & Lebih besar dari Mi +1,5 SDi & Fo1 & Fr1 & Sangat Baik \\
\hline 2 & >Mi s.d Mi + 1,5 SDi & Fo2 & FR2 & Baik \\
\hline 3 & Mi- 1,5 SDis.d Mi & Fo3 & FR3 & Kurang Baik \\
\hline 4 & Kurang dari Mi- 1,5 SDi & Fo4 & Fr4 & Tidak Baik \\
\hline
\end{tabular}

Keterangan: $\mathrm{Mi}=$ Mean Ideal $=1 / 2($ skor maksimal + skor minimal $)$

$\mathrm{SDi}=1 / 6$ (skor maksimal- skor minimal).

\footnotetext{
${ }^{46}$ Ibid, 107

${ }^{47}$ Suharsimi Arikunto dalam Manumpak Silitonga. Metode Penelitian STTSU, (Medan, 2015),106
} 


\section{HASIL PENELITIAN DAN PEMBAHASAN \\ 1. Deskripsi Data Penelitian.}

Berdasarkan hasil analisis data penelitian, disajikan hasil uji menggunakan SPSS for Windows versi 22. Hasil perhitungan menunjukkan sebagai berikut: Mean sebesar 69,24, Median 68, Mode 64 , Standar Deviasi 15,61, Skor minimum 30 dan Skor maksimumya 112.

Distribusi frekuensi data pemahaman pemuda terhadap makna kebaktian dapat ditentukan sebagai berikut:
a. $\quad$ Range $=$ skor tertinggi-skor terendah $=82$
b. Banyak kelas $=1+3,3 \log n=9$
c. Panjang kelas $=$ rentang $:$ banyak kelas $=10$

Hasil perhitungan ditunjukkan pada table berikut ini.

Tabel 2.Distribusi Frekuensi Skor Pemahaman Pendapat terhadap Makna Kebaktian

\begin{tabular}{|c|c|c|c|c|}
\hline Kelas & Interval Kelas & F A & F R & F K \\
\hline 1 & $30-39$ & 3 & 2,857 & 3 \\
\hline 2 & $40-49$ & 6 & $3,8105,715$ & 9 \\
\hline 3 & $50-59$ & 14 & 13,334 & 23 \\
\hline 4 & $60-69$ & 20. & 28,571 & 43 \\
\hline 5 & $70-79$ & 30 & 32,381 & 73 \\
\hline 6 & $80-89$ & 20 & 19,048 & 93 \\
\hline 7 & $90-99$ & 6 & 5,714 & 99 \\
\hline 8 & $100-109$ & 4 & 3,810 & 103 \\
\hline 9 & $110-119$ & 2 & 1,904 & 105 \\
\hline \multicolumn{2}{|r|}{ Total } & 105 & 100 & \\
\hline
\end{tabular}

Sementara hasil perhitungan tingkat kecenderungan Pemahaman Pemuda terhadap Manfaat Kebaktian minggu diperlihatkan pada table 3 di bawah ini.

$\mathrm{Mi}=1 / 2(125+25)=75$ dan SDi $=1 / 6(125-25)=16,666$

Tabel 3. Distribusi Frekuensi dan Kategori skor Variabel Penelitian.

\begin{tabular}{|l|l|l|l|l|}
\hline Kelas & Interval Kelas & & F \% & Kategori \\
\hline 1 & Lebih besar dari 100 & 6 & 6,3 & Sangat Baik \\
\hline 2 & 75 s.d 100 & 56 & 58,8 & Baik \\
\hline 3 & 50 s.d 74 & 34 & 35,7 & Kurang Baik \\
\hline 4 & Kurang dari50 & 9 & 9,45 & Tidak Baik \\
\hline
\end{tabular}

Mengamati table 3 ternyata 6 orang $(6,3 \%)$ berada pada kategori sangat baik, 56 orang $(58,8 \%)$ pada kategori baik, 34 orang $(35,7 \%)$ dalam kategori kurang baik dan sisanya sebanyak 9 orang $(9,45 \%)$ pada kategori tidak baik. Hasil uji di atas memberi pengerian bahwa pemahaman pemuda terhadap makna kebaktian di GPII Sola Scriptura Medan cenderung baik.

\section{Pembahasan Hasil Penelitian}

Berdasarkan deskripsi data dan hasil pengujian data Pengamatan pemuda terhadap makna kebaktian Minggu di GPII Sola Scriptura Medan, dilakukan pembahasan atas hasil-hasil penelitian sebagai berikut:

a. Rerata skor data penelitian (M) sebesar 69,24, Median sebesar 68, Modelnya 64, Standar Deviasi 15,61, Skor terendah 30 dan skor tertinggi 112. Skor tertinggi yang diharapkan dengan jumlah butir instrument 25 seharusnya mencapai 125 . Ternyata masih terdapat skor 
yang jauh dari harapan yang sekaligus menjelaskan bahwa masih terdapat subjek penelitian yang memiliki pemahaman kurang baik terhadap makna kebaktian gereja di GPII Sola Scriptura Medan. Berdasarkan temuan wawancara dengan pemuda menyebutkan bahwa kebaktian yang berlangsung sering tidak tertarik bagi mereka dan berakibat terhadap kualitas pemahamannya.

Hal ini tidak bersesuaian dengan hasil penelitian Marsi Bombonan Bantesalu (2019) yang menyatakan bahwa pemahaman yang benar terhadap kebaktian akan memiliki hubungan yang erat terhadap kehidupan orang Kristen.

b. Berdasarkan uji tingkat kecenderugan variable pemahaman pemuda terhadap makna kebaktian minggu menunjukkan bahwa 62 orang $(65,1 \%)$ dari subjek penelitian berada pada kategori baik dan sangat baik, dan 43 orang $(45,15 \%)$ pada kategori kurang baik dan tidak baik. Hasil penelitian ini menunjukkan bahwa masih cukup banyak di antara subyek penelitian yang perlu ditingkatkan pemahamannya terhadap makna kebaktian minggu. Kesimpulan ini juga bersesuaian dengan capaian skor hasil pengamatan bahwa masih ada skor yang sangat rendah tetapi kesimpulan akhirnya menetapkan bahwa pemahaman pemuda terhadap makna kebaktian minggu cenderung baik. Kesimpulan hasil penelitian ini dapat sesuai dengan penelitian yang dilakukan oleh Marsi Bombonan Bantesalu (219), Eddy Banne, Daud Manno (2020) dan Fernando Tambunan (2020) yang pada umumnya menyimpulkan bahwa kebaktian Minggu sangat perlu untuk menentukan karakter pemuda. Hasil penelitian ini juga bersesuaian dengan temuan penelitian Debora Nugrahenny Christimoty (219) yang menyimpulkan, bahwa pemahaman yang benar tentang kebaktian minggu akan dapat mendekatkan diri kepada Tuhan.

c. Berdasarkan hasil pengamatan langsung dan wawancara di lapangan terhadap penatua gereja telah menunjukkan bahwa sebagian besar dari subyek penelitian ini diakuinya telah dengan sepenuh hati untuk mengikuti kegiatan kebaktian gereja, bahkan cukup banyak di antara pemuda yang aktif dalam perkumpulan koor muda-mudi, grup musikal gerejani, guru-guru sekolah minggu dan pada kegiatan gereja lainnya. Tetapi tidak jarang pula di antara pemuda yang susah diarahkan untuk berperan dalam kegiatan-kegiatan yang dilakukan sehingga hasil pengamatan dan wawancara bersesuaian dengan hasil pengolahan data yang dijaring melalui angket dan bersesuaian dengan hasil penelitian yang dilakukan oleh Eddy Banne, Daud Manno, Debora Nugrahenny Christioty.

\section{KESIMPULAN IMPLIKASI DAN SARAN}

\section{Kesimpulan}

Berdasarkan uraian-uraian terdahulu dan hasil analisis data serta pemahaman hasil penelitian yang dilakukan, maka dapat disimpulkan sebagai berikut:

a. Masih terdapat sebanyak 35,7 \% subyek penelitian yang memiliki pemahamannya terhadap makna kebaktian di GPII Sola Scriptura Medan dan ternyata 9,45 \% lainnya masih berada pada kategori pemahamannya yang tidak baik.

b. Hanya 6,3 \% dari subyek penelitian yang memiliki pemahaman terhadap makna kebaktian di GPII Sola Scriptura Medan dalam kategori sangat baik dan sebagian besar dari subjek penelitian berada pada kategori baik yakni 58, 8\%.

c. Dari simpulan butir 1 dan 2 dapat disimpulkan bahwa pemahaman pemuda terhadap makna kebaktian di GPII Sola Scriptura Medan sudah cenderung baik. Simpulan dan uji statistik ini bersesuaian dengan hasil pengamatan langsung di lapangan dan hasil wawanara yang dilakukan peneliti. 


\section{Implikasi Hasil Penelitian}

Bertitik tolak dari hasil penelitian maka adapun implikasi dalam penelitian ini adalah sebagai berikut:

\section{a. Implikasi Teoritis}

Peningkatan pemahaman pemuda terhadap makna kebaktian gereja dapat dilakukan dengan: Pemuda sebaiknya memiliki keinginan yang kuat untuk lebih aktif dalam setiap kegiatan gerejani. Pemuda berkeinginan untuk berusahan ke arah pencapaian tujuan dilakukannya kebaktian gereja. Pemuda sebaiknya memiliki kepercayaan diri bahwa dengan mengikuti kebaktian gereja akan memberikan makna yang berguna untuk kehidupannya. Dalam setiap bertindak para pemuda seharusnya tidak lupa akan adanya Tuhan yang mahatahu akan segala sesuatu tindakan.

\section{b. Implikasi Kebijakan}

Berdasarkan simpulan hasil penelitian tersebut, dapat dilakukan upaya peningkatan pemahaman pemuda tehadap makna kebaktian di GPII Sola Scriptura Medan melalui berbagai cara pendekatan dan pendampingan pemuda gerejani. Penelitian telah menyimpulkan bahwa pemahaman pemuda terhadap makna kebaktian gereja sudah cenderung baik $(65,1 \%)$, tetapi masih cukup banyak dikalangan pemuda yang memiliki pemahaman terhadap makna kebaktian gereja dalam kategori kurang baik $(45,15 \%)$.

Upaya-upaya yang mugkin dilakukan untuk peningkatan pemahaman pemuda tehadap makna kebaktian di GPII Sola Scriptura Medan antara lain dengan: Pertama: Kepemimpinan yang sedang berlangsung di gereja perlu dipertahankan serta diupayakan peningkatannya dengan jalan menggali pengetahun tentang kepemiminan kristiani dalam upayanya agar memiliki pengetahuan yang cukup mendekatkan diri dengan para pemuda gereja. Kedua: Penyelenggaraan kebaktian gereja perlu dilakukan secara baik untuk meningkatkan minat pemuda selama kebaktian, misalnya dengan sajian nyanyian, musik dan hotbah yang menarik untuk kalangan pemuda. Ketiga: Selama berlangsungnya kebaktian gereja, perlu dilakukan pendampingan duduk oleh para petugas gereja terutama di barisan belakang untuk mengawasi agar para pemuda tidak ada yang berisik dan atau keluar masuk gereja. Keempat: Gereja perlu mengupayakan adanya kegiatan rutinitas secara terjadwal aktivitas pemuda di gereja seperti latihan-latihan musik gerejani, koor muda- mudi, dan penelahan Alkitab. Kelima: Dalam keluarga diperlukan pembiasaan agar pemuda senang memanjatkan doa, mengikuti kebaktian keluarga setiap malam dan pembiasaan untuk membaca Alkitab. Keenam: Masih dalam upaya untuk menigkatkan pemahaman pemuda tehadap makna kebaktian di GPII Sola Scriptura Medan, diharapkan para guru agama memberikan tugas kepada para siswanya untuk mencatat ringkasan khotbah yang diterima di gereja sehingga dengan cara ini para pemuda akan dengan tekun mengikuti acara demi acara kebaktian.

\section{SARAN- SARAN}

Berdasarkan simpulan dan Implikasi hasil penlitian, dikemukakan beberapa saran bagi berbagai pihak yang berkaitan langsung maupun yang tidak langsung dengan upaya penigkatan pemahaman pemuda tehadap makna kebaktian di GPII Sola Scriptura Medan, sebagai berikut: Dalam penelitian masih ditemukan cukup banyak responden yang memiliki pemahaman pemuda terhadap makna kebaktian dalam kategori kurang baik $(35,7 \%)$ dan masih juga terdapat 9,45\% dalam kategori tidak baik. Hal ini memberi petunjuk betapa pentingnya pengawasan melekat yang harus dilakukan oleh para orang tua dalam keluarga, pengawasan guru agama di sekolah dan pengawasan serta pendampingan para penatua gereja.

Melalui pengawasan orang tua dapat dilakukan dengan berkumpul bersama, berdiskusi terbuka antar sesama dan melaksanakan kebaktian keluarga harian. Pendampingan dengan jalur guru agama dapat dilakukan dengan cara jalinan komunikasi yang sangat akrab, 
kegiatan belajar mengajar yang benar-benar menggugah hati siswa, memberi tugas- tugas keagamaan. Sedangkan melalui jalur gereja dapat dilakukan dengan pengawasan dan atau pendampingan duduk di sekitar pemuda, menggiatkan kelompok musik gereja, menggiatkan kelompok koor muda- mudi, melibatkan muda-mudi dalam pelayanan anak sekolah minggu, dan melibatkan pemuda untuk song leader, pengumpulan persembahan dan kegiatan-kegiatan gerejani. 


\section{DAFTAR PUSTAKA :}

Alkitab. (2017). Lembaga Alkitab Indonesia.

Arikunto, S. (2018). prosedur penelitian. Rineka Cipta.

Benyamin, N. C. (2018). Spiritualitas dalam doa Bapa Kami. Abdiel :

Khazanah Pemikian Teologi, Pendidikan Agama Kristen Dan Musik Gereja, 2 No 2, 32-42.

Bombongan Bantesalu. (2019). Refleksi Teologis tentang makna Ibadah yang sejati. Teologi.

Brownlee, M. (2004). Tugas manusia dalam dunia milik Tuhan. BPK Gunung mulia.

C, A. J. L. (2012). Unsur- unsur Liturgia. BPK Gunung Mulia. Christimoty, D. N. (2019a). Teologi Ibadah dan Kualitas Penyelenggaraaan Ibadah: Sebuah Pengantar. Pasca: Jurnal Teologi Dan Pendidikan Agama Kristen, 15(1), 1-7.

Christimoty, D. N. (2019b). Tinjauan Teologis tentang Ibadah bagi pelaksanaan Misi. Sekolah Tinggi Teologi Baptis.

Darsono Ambarita. (2020). pertahanan Gereja Abad permulaan:

Kanon, Pengakuan Iman, Jabatan Rasuli dan Relevansinyapada gereja masa kini. STTPK, 6 No.1.

Daud Manno, E. B. (2020). Analisis dasar dan Teologisterhadap pelaksanaan Ibadah Online Pasca Pandemi Covid-19 n. Teologi Dan Pelayanan Kristiani EPIGRAPHE.

Dessy Handayani. (2020). Implementasi Hukum Allah dalam matius 22:34-40 bagi pengembangan komunitas Kristen. Stapin, 11 No. 1.

Diater Becker. (2019). Pedoman Dogmatika. BPK Gunung Mulia.

Dwiraharjo, S. (2018). Persembahan Yang Hidup Sebagai Buah dari Pembenaran oleh iman menurut Roma 12:1-2. Prudentia: Jurnal Teologi Dan Pendidikan Kristiani, 1, No 1, 1-24.

Fernando Tambunan. (2020). Teologi Ibadah dan Kualitas Penyelenggaraan Ibadah. Teologi Dan Pelayanan Kristiani EPIGRAPHIE.

Firman Panjaitan dan Martin Steven Lumingkewas. (2019). Ibadah Jemaat Kristen Kontemporer Abd 21 dan Tinjauan Kritis- Lirturgis. Fidei: Jurnal Teologi Sistematiak Dan Pratika, 2, 159-182.

Gunawan, F. (2015). Interpretasi Doa Bapa Kami. Cyprian. Jurnal Amanat Agung, 11 No. 2, 379-398.

Jasmin, M. (2006). Konsep Syafaat dalam rencana total Allah. Jaffray, 4 No $1,34-40$.

Jefri Wungow, F. O. (2021). pengaruh pujian dan penyembahan terhadap pertumbuhan jemaat. In Theos, 1 No. 1 . 
Jheremia Djadi. (2012). Spiritual Seorang Pelayan Tuhan. STT Jaffray, 10 No. 1.

Kelelufna, J. H. (2021). Doa Syafaat untuk Sodom. Kerusso \, 6 No. 1, $1-18$.

Kuswana. (2012). Taksonomi Kognitif. PT. Remaja Rosdakarya.

Negara, S. (2019). UU No 40 tentang kepemudaan. Sekneg.

Panjaitan, F., \& Lumingkewas, M. S. (2019). Ibadah Jemaat Kristen Kontemporer Abad 21 Dan Tinjauan Kritis-Liturgis. FIDEI: Jurnal Teologi Sistematika Dan Praktika, 2, 159-182.

Rohani, S. (2013). Analisis Pengaruh Nyanyian Jemaat terhadap Kualitas Ibadah Gereja Protestan di Indonesia bagian Barat (GPIB) Jemaat Bukit Zaitun Makassar. Jaffray, 11 No. 2, 140-164.

Rohani Siahaan. (2012). Memahami Nyanyian Jemaat sebagai Sentral Musik Gereja Apa dan Bagaimana? STT Jaffray, 10, No 2.

Sampitmo Habeahan. (2020). Seni dan Keterampilan Berkhotbah. Teologi Pemberitaan Firman Tuhan. Cv. Mitra.

Santoso, D. S. B. (2020). Peran Khotbah Gembala Sidang dalam pertumbuhan Rohani Jemaat. Magnum Opus: Jurnal Teologi Dan Kepemimpinan Kristen, 1 No. 2, 88-97.

Saramae, P. B. (2014). Konstutitusi Liturgi Konsili Vatikan II:

Prasejarah, sejarah dan Naskahnya. Orientasi Baru, 1 No. 2, 88-97.

Suharsimi Arikunto dalam Manumpak Silitonga. (2015). metode Penelitian. STTSU.

Sudjana. (2005). Metoda Statistika. Tarsito.

W.J.S Poerwadarminta. (2001). Kamus Besar Umum Bahasa Indonesia. Balai Pustaka.

Wahyu Ishardino Satries. (1989). Peran Serta Pemuda Dalam Pembangunan Masyarakat. Madaniedisi.

http;//ethesesuin-malang.ac.id 